\title{
THE FLAVONOIDS CONTENT IN LEAVES AND FRUITS OF PAPAYA (Carica papaya L.) VAR. CALIFORNIA AND VAR. GANDUL
}

\author{
Arliana fajin, Woro Anindito Sri Tunjung \\ Faculty of Biology Universitas Gadjah Mada \\ Correspondence author: w_anindito@yahoo.co.nz
}

\begin{abstract}
Papaya has widely used as traditional medicine. Papaya leaves and fruits contain flavonoids that can be used as anti-bacterial, anti-fungal and anti-cancer. Flavonoid is one of secondary metabolite products. Flavonoids are ubiquitous in photosynthesis cells. Flavonoid content can be affected by enzyme which arranged from protein, meanwhile difference formation of gene can affect protein content. The aim of this research was to measure flavonoid content in leaves and fruits of genetical engineering papaya (var. California) and local papaya (var. Gandul). Leaf and fruit samples were dried to make powder. Samples were reflucted with $\mathrm{HCl} 4 \mathrm{~N}$ and extracted with Eter (three times). $\mathrm{NaNO}_{3} 5 \%, \mathrm{AlCl}_{3} 10 \%$ and $\mathrm{NaOH} 1 \mathrm{M}$ were added into samples then analyzed using spectrophotometer (á $454 \mathrm{~nm}$ ) with quercetin as standard. Data analyzed using T test $(p<0,05)$. The result showed in California leaves has higher concentration of flavonoid $(0,73 \% \mathrm{w} /$ $\mathrm{w} \pm 0,05)$ than Gandul leaves $(0,69 \% \mathrm{w} / \mathrm{w} \pm 0,08)$. meanwhile California fruits significantly has lower flavonoid concentration $(0,59 \% \mathrm{w} / \mathrm{w} \pm 0,02)$ than gandul fruits $(0,8 \% \mathrm{w} / \mathrm{w} \pm 0,03)$. Difference of flavonoids content in leaf and fruit indicates genetic variation affect flavonoids translocation among organ. According to variety California fruits have lower concentration than it's leaves, meanwhile in gandul variety fruits have higher concentration than leaves. In conclusion, difference of flavonoid content in California variety and gandul variety indicates different ability in flavonoids distribution among individual.
\end{abstract}

Key words: flavonoids, Carica papaya L. var. California, Carica papaya L. var. Gandul, spectrophotometry

\section{INTRODUCTION}

Traditional medicine has widely used as alternative medication due to its low side effects. One of traditional medicine that has known in Indonesia is Papaya (Dayanti and Suyatno, 2012). Papaya, that introduced from Mexico, has well grown in Indonesian tropical climate. Papaya leaves and fruits often used as food and medication (Wijayakusuma et. al., 1994). Papaya leaves were believed as their medical advantages in cancer, lactation, digestion and dengue fever. Meanwhile, papaya fruits has used as anti-cancer, stroke prevention and blood cholesterol control (Otsuki et al., 2010)..

Papaya used as traditional medicine because of its secondary metabolite activities. Secondary metabolites such as alkaloid, flavonoid, terpenoid, karetenoid, etc are non nutrient chemical products derived from primer metabolites. They were produced mainly at stress condition. Regulation of secondary metabolite is very complex, generally secondary metabolite is regulated by enzyme but substrat can affects secondary metabolite product (Seigler, 1995 ).

One of secondary metabolite products is flavonoid. Flavonoids are ubiquitous in photosynthesis cells. The character of flavonoids are : flavonoid has 15 carbon atom with two aromatis ringbinded, have 11 group are flavones, flavonol, flavan-3,4-diol, flavanon, flavanonol, isoflavon, katekin, antosianin, auron, khalkon, dan dihidrokhalkon, give bitter taste, and yellow color in organs. 


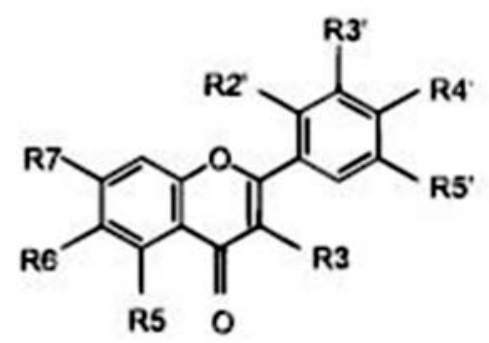

Figure 1. Chemical structure of flavonoid

The function of flavonoids in flowers is to provide glaring color to attract plant pollinators. These compounds are believed to promote physiological survival of plant, protecting it from fungal pathogens and UV-B radiation. Flavonoids are involved in energy transfer, growth regulation, respiration, photosynthesis, morphogenesis and sex determination (Cashin \& Lamb, 2005). Previous study showed that flavonoids has several function i.e. anti-inflamation, anti-tumor and anti-cancer (Otsuki et.al., 2010). Furthermore papaya fruits contain vitamins (A, C and E) and other antioxidant compounds such as flavonoids (Sukardiman et.al., 2006).

There are several local papaya varieties in Indonesia: Cibinong, Jingga, Bangkok and Gandul (Muktiani, 2012). The latest developed variety was California that was created by researchers in Bogor Agricultural Institute. California papaya is genetic engineering product from solo papaya and cicurug bogor papaya.

Genetical engineering is a method that used to change genetic formation in plant. There are four methods in genetical engineering i.e sexual breeding, somatic hibridisation, mutation and DNA recombinant. Genetical engineering give effects on nutrition content, plant defence, fruit taste and structure. Genetical engineering that used in papaya breeding affects cell metabolism include secondary metabolites such as flavonoids (Seigler, 1995). Nowadays, genetic engineered variety of papaya preferable to consume than the local one. Usually genetic engineered varieties have bigger size, sweeter taste, thick fruit peel, and more interesting colour. On the other hand information about nutrition or secondary metabolite content are very limited. Therefore, this research was aimed to measure the flavonoids content in leaves and fruits of Gandul and California variety as representative of local and genetic engineered Papaya variety respectively.

\section{MATERIALS AND METHODS}

This research was conducted on February to March 2013 in Integrated research and analysis laboratorium (LPPT) Gadjah Mada University.

\section{Sampling}

Leaf and fruit samples were taken at same age and location, in Pundong 3 Sleman Yogyakarta. Samples were dried using oven then grinded to make powder.

\section{Preparation of sample}

Samples were reflucted with $\mathrm{HCl} 4 \mathrm{~N}$ to release secondary s from cell vacuola and transform glicoside to aglicon and also to hydrolyze glicosic bound. Samples were extracted with non polar solvent i.e. Eter (three times). $\mathrm{NaNO}_{3} 5 \%$ was added and incubated for 5 
minutes to ionize the most acid hydroxil complex of flavonoids. Then, $\mathrm{AlCl}_{3} 10 \%$ was added to stimulate acid complexes between hydroxil groups and ketones. $\mathrm{NaOH} 1 \mathrm{M}$ was added as buffer agent. This complexes produces yelow colour.

\section{Analisys of flavonoid content}

Samples then analyzed using spectrophotometer (á $454 \mathrm{~nm}$ ) with quercetin as standard. Data analyzed using $T$ test $(p<0,05)$ to know the significancy among two groups.

\section{RESULTS AND DISCUSSION}

Differ variety of papaya showed differ morphological on its habitus, leaves and fruit. The difference between Gandul var and California var can be seen in table 1.

Table 1. Morphology character of Gandul papaya and California papaya

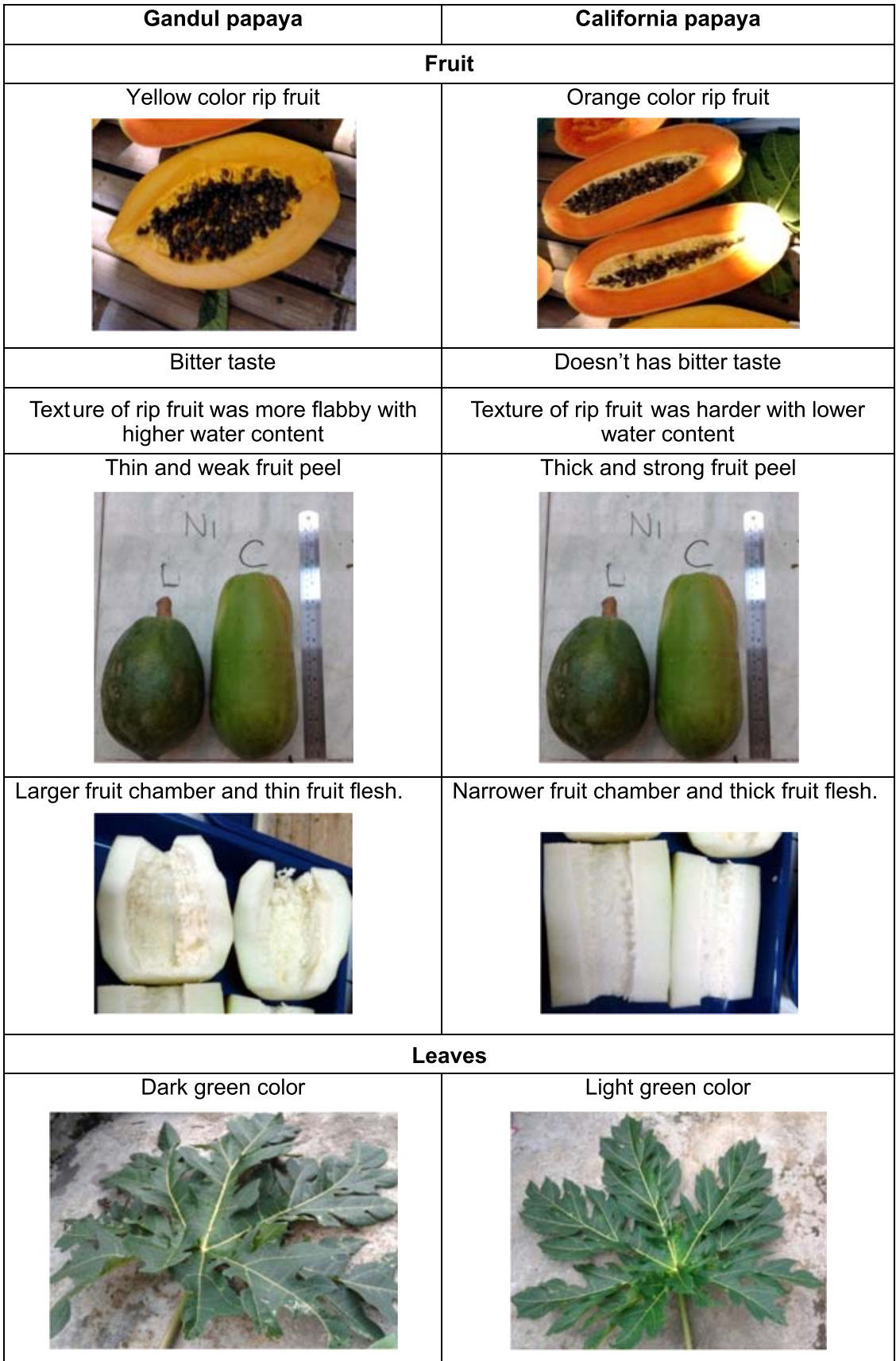


According muktiani, 2011 california papaya has weight about 800 gram to 1200 gram. Fruit shape is like bullet, fruit peel is thick, surface peel is flat and has sweet degree is $10-11$ brix.

The result of flavonoids concentration measurement in papaya leaves showed in Figure 1. California leaves has higher flavonoids concentration $(0,73 \% w / w \pm 0,05)$ than Gandul leaves $(0,69 \% \mathrm{w} / \mathrm{w} \pm 0,08)$ although there were not significantly difference. It possibly because papaya California leaves has higher mass and density compare to Gandul which caused higher flavonoids concentration.

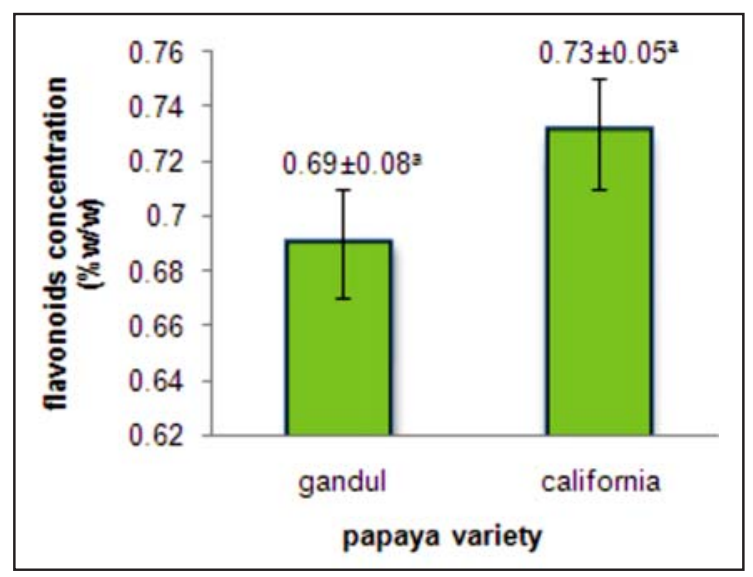

Figure. 1. Flavonoids concentration in Gandul and California leaves

The result of flavonoids concentration measurement in papaya fruits showed in Figure 2. California fruits significantly has lower flavonoid concentration $(0,59 \% \mathrm{w} / \mathrm{w} \pm 0,02)$ than gandul fruits $(0,8 \% \mathrm{w} / \mathrm{w} \pm 0,03)$. It may be caused by early flavonoids transport to fruits in Gandul variety. Fruits organoleptic test also showed that Gandul variety has bitter taste than California variety at the same age. Bitter flavor is one of Flavonoid characteristic

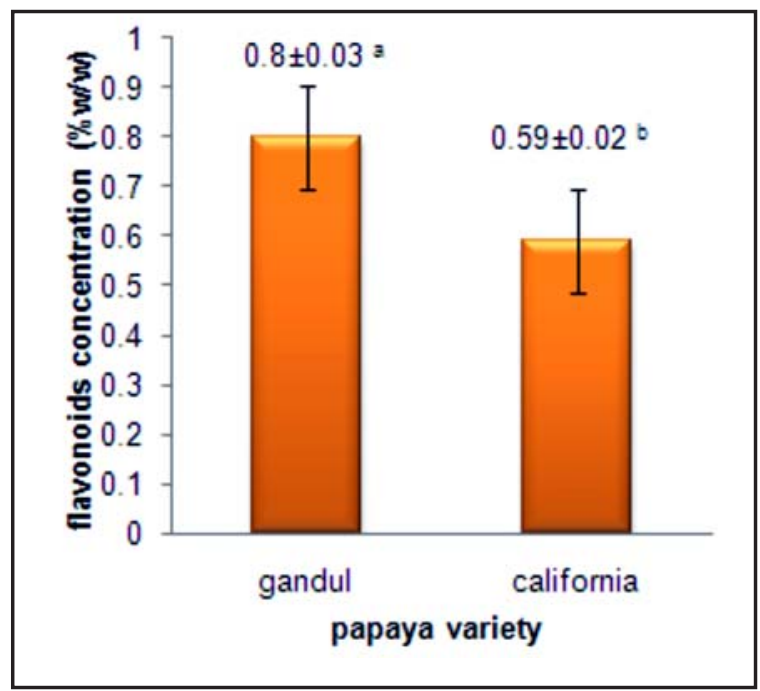

Figure 2. Flavonoids concentration in Gandul and California fruits

Difference of flavonoids content in leaf and fruit indicates genetic variation give difference effect on flavonoids translocation among organ. According to variety, California fruits have lower concentration than it's leaves, meanwhile in gandul variety fruits have higher con- 
centration than leaves. Information about nutrition and secondary metabolite content are important thus costumer can choose better variety according to their purpose, for example : for food or traditional medicine.

\section{CONCLUSION}

Difference of flavonoid content between California variety and Gandul variety indicates different ability in flavonoids distribution among individual.

\section{REFERENCES}

Cushnie, T.T.P., and A. J. Lamb. 2005. Antimicrobial activity of flavonoids. International Journal of Antimicrobial Agents vol.26:343-356

Dayanti, R., dan Suyatno. 2012. Aktivitas Antioksidan Ekstrak Metanol Bagian Batang Tumbuhan Paku (Nephrolepis radians). UNESA Journal of Chemistry Vol.1:1

Muktiani. 2011. Bertanam Varietas Unggul Pepaya California. Pustaka Baru Press: Yogyakarta. Hal: 18

Otsuki, N., N. H. Dang, E. Kumagai, A. Kondo, S. Iwata, and C. Marimoto. 2010. Aqueous Extract of Carica papaya Leaves Exhibits Anti-tumor Activity and Immunomodulatory. Journal of Ethnopharmacology. Vol. 127:760-767

Sukardiman, W. Ekasari, P.P. Hapsari. 2006. Aktivitas Antikanker dan Induksi Apoptosis Fraksi Kloroform Daun Pepaya (Carica papaya L) terhadap Kultur Sel Kanker Mieloma. Media Kedokteran Hewan. Vol. 22, No. 2. Hal 104-111.

Seigler, D.S. 1995. Plant Secondary Metabolism. Kluwer Academic Publisher: Netherlands p: 3

Wijayakusuma, H., S. Dalimartha, and A.S. Wirian. 1994. Tanaman Berkhasiat Obat di Indonesia. Pustaka Kartini: Jakarta. Hal:102-103 